BIOEDUSAINS: Jurnal Pendidikan Biologi dan Sains

Volume 2, Nomor 1, Juni 2019

e-ISSN : 2598-7453

DOI: https://doi.org/10.31539/bioedusains.v2i1.641

\title{
EKSPLORASI JENIS BAMBU DI KECAMATAN RAWAS ULU KABUPATEN MURATARA
}

\author{
Reny Dwi Riastuti ${ }^{1}$, Yuli Febrianti ${ }^{2}$, Trisnawati Panjaitan ${ }^{3}$ \\ STKIP-PGRI Lubuklinggau ${ }^{1,2,3}$ \\ renydwiriastuti09@gmail.com ${ }^{1}$
}

\begin{abstract}
ABSTRAK
Penelitian ini bertujuan:untuk mengeksplorasi jenis Bambu (Bambusa sp) di Kecamatan Rawas Ulu Kabupaten MurataraTeknik pengumpulan data dalam penelitian ini adalah sebagai berikut: (a). eksplorasi (b) Wawancara (c). Dokumentasi; Prosedur penelitian adalahObservasi, Penelitian lokasi, Analisis sampel, Identifikasi sampel, Deskripsi sampel, Faktor ekologi, Manfaat bambu; (1). Hasil identifikasi terdapat 4 genus yang terdiri dari (Gigantochloa, Bambusa, Densrocalamus, dan Schizoctachyum). Terdapat 6 spesies yang terdiri dari (Gigantochloa apus, Gigantochloa pseudoarundin, Bambusa vulgaris, Bambusa glaucescens, Schizoctachyum blumei, Densrocalamus asper); (2). Faktor ekologi bambu adalah $\mathrm{pH}$ tanah 4,9-7,0 dan suhu udara $25-30^{\circ} \mathrm{C}$ dengan kelembaban tanah 51-71\%; (3). Bambu dapat dimanfaat sebagai bahan konstruksi ringan seperti kandang ternak, pagar, tanaman hias, industri kerajinan rumah tangga dan anyaman. Simpulan dari penelitian ini adalah terdapat 4 genus dan 6 jenis bambu yang hidup berbeda.
\end{abstract}

Kata Kunci: eksplorasi, bambu

\begin{abstract}
This study aims: (1). To eksploration the type of Bamboo (Bambusa sp) in Rawas Ulu District, Muratara Regency. Data collection techniques in this study are as follows: (a). eksploration (b) Interview (c). Documentation; The research procedure is observation, location research, sample analysis, sample identification, sample description, ecological factors, bamboo benefits; (1). The results of identification there are 4 genera consisting of (Gigantochloa, Bambusa, Densrocalamus, and Schizoctachyum). There are 6 species consisting of (Gigantochloa apus, Gigantochloa pseudoarundin, Bambusa vulgaris, Bambusa glaucescens, Schizoctachyum blumei, Densrocalamus asper); (2). The ecological factors of bamboo are soil pH of 4.9-7.0 and air temperature of 25-30oC with soil moisture of 51-71\%; (3). Bamboo can be used as light construction materials such as livestock pens, fences, ornamental plants, household handi crafts and woven industries. The conclusion of this study is that there are 4 genera and 6 types of bamboo that live differently.
\end{abstract}

Keywords: eksploration, bambu 


\section{PENDAHULUAN}

Indonesia terdapat sekitar 125 jenis bambu, termasuk yang masih banyak tumbuh liar dan belum banyak dimanfaatkan. Adapun jenis bambu yang telah dimanfaatkan oleh masyarakat seperti bambu Apus, bambu Ater, bambu Andong, bambu Betung, bambu Kuning, bambu Hitam (wulung), bambu Tutul, bambu Cendani, bambu Cangkoreng, bambu Perling, bambu Taminang, bambu Loleba, bambu Batu, bambu Balangke, bambu Sian, bambu Jepang, bambu Gendang, bambu Bali, dan bambu Pagar. Tanaman bambu adalah tanaman yang serba guna, mulai dari akarnya, batangnya hingga daunnya yang dapat dimanfaatkan dalam kehidupan sehari-hari (Muhtar et al, 2017).

Menurut Sinyo et al (2017) bambu adalah salah satu sumber daya alam yang dapat dimanfaatkan dan digunakan oleh masyarakat karena memiliki sifatsifat yang menguntungkan yaitu batang yang kuat, lurus, rata, keras, mudah dibelah, mudah dibentuk, mudah dikerjakan dan diangkut. Sedangkan menurut Tim Elsppat (1997) bambu adalah tanaman yang paling cepat tumbuh. Bambu mencapai ketinggian maksimum setalah 2-4 bulan. Berdasarkan pengertian di atas dapat diketahui bahwa bambu adalah suatu tanaman yang dapat dimanfatkan oleh masyarakat, karna sumber daya alamnya yang banyak dan memiliki sifat-sifat yang menguntungkan seperti batangnya yang kuat, rata, keras, mudah dibelah dan bambu menjadi bahan serba guna dan tanaman yang cepat tumbuh di Indonesia.Kecamatan Rawas Uu Kabupaten Muratara memiliki banyak jenis bambu. Kecamatan ini banyak ditumbuhi bambu dikarenakan memiliki topografi sesuai dengan habitat tumbuhnya berbagai jenis bambu.

\section{METODE PENELITIAN}

Penelitian menggunakan metode metode eksplorasi dan pengamatan langsung di kecamatan Rawas Ulu. Jenis penilitian adalahdeskriptif kualitatif karena data yang dikumpulkan dan dianalisis diperoleh dari situasi yang wajar dari fenomena yang bersangkutan.Pada tahap pertama yang dilakukan dalam penelitian ini yaitu melakukan identifikasi jenis-jenis bambu yang ada diKecamatan Rawas Ulu Kabupaten Muratara. Menurut Sugiyono (2015) pengumpulan data dapat dilakukan dengan cara observasi, wawancara, dan dokumentasi data terkait.

Menurut Abrori (2016) adapun langkah-langkah di dalam melakukan pengidentifikasian adalah sebagai berikut:

1. Observasi adalah suatu usaha sadar untuk mengumpulkan data yang dilakukan secara sistematis, dengan prosedur yang terstandar atau merupakan kegiatan meninjau, menggawasi dan mengamati.

2. Penelitian lokasi secara purposive sampling

3. Analisis sampel meliputi pengukuran panjang batang dan ruas, penghitungan dan penilaian terhadap ciri dari setiap sampel dengan mengunakan alat-alat 
pengukur (mistar dan meteran) dan pemotong (pisau dan parang). Kemudian dicocokan dengan ciri dan sifat yang diuraikan dalam buku-buku referensi.

4. Identifikasi sampel yaitu dengan menghitung semua ciri dan sifat yang sangat mencolok dari masing-masing jenis tumbuhan bambu diambil agar bisa membedakan antara tumbuhan yang satu dengan yang lain.

5. Deskripsi sampel yaitu dari analisis dan identifikasi terhadap ciri dan sifat dan sampel tumbuhan bambu. Selanjutnya dibuat deskripsi lengkap dari setiap jenis.

6. Faktor ekologi yaitu untuk mengukur $\mathrm{pH}$ tanah dan kelembaban tanah mengunakan soil tester dan suhu udara dengan higrometer yang dilakukan satu pengulangan yaitu pada siang hari.

7. Manfaat bambu yaitu dengan membuat lembar wawancara pada saat penelitian.

\section{HASIL PENELITIAN}

Adapun hasil penelitian yang peneliti lakukan di Kecamatan Rawas Ulu Kabupaten Muratara, yang mana dari sepuluh desa terdapat enam jenis bambu yang ditemukan oleh peneliti, keenam jenis bambu ini dapat dilihat dari tabel identifikasi jenis bambu 4.1 di bawah ini:

Tabel Identifikasi Jenis Bambu

\begin{tabular}{|c|c|c|c|}
\hline No & Gambar & & Klasifikasi \\
\hline 1 & & $\begin{array}{l}\text { Kingdom } \\
\text { Divisi } \\
\text { Subdivisi } \\
\text { Kelas } \\
\text { Ordo } \\
\text { Famili } \\
\text { Genus } \\
\text { Spesies }\end{array}$ & $\begin{array}{l}\text { : Plantae } \\
\text { : Spermatophyta } \\
\text { : Angiospermae } \\
\text { : Monokotiledoneae } \\
\text { : Graminales } \\
\text { : Gramineae } \\
\text { : Gigantochloa } \\
\text { : Gigantochloa apus }\end{array}$ \\
\hline 2 & & $\begin{array}{l}\text { Kingdom } \\
\text { Divisi } \\
\text { Subdivisi } \\
\text { Kelas } \\
\text { Ordo } \\
\text { Famili } \\
\text { Genus } \\
\text { Spesies }\end{array}$ & $\begin{array}{l}\text { : Plantae } \\
\text { : Spermatophyta } \\
\text { : Angiospermae } \\
\text { : Monokotiledoneae } \\
\text { : Graminales } \\
\text { : Gramineae } \\
\text { : Gigantochloa } \\
\text { : Gigantochloa pseudoarundin }\end{array}$ \\
\hline 3 & & $\begin{array}{l}\text { Kingdom } \\
\text { Divisi } \\
\text { Subdivisi } \\
\text { Kelas } \\
\text { Ordo } \\
\text { Famili } \\
\text { Genus } \\
\text { Spesies }\end{array}$ & $\begin{array}{l}\text { : Plantae } \\
\text { : Spermatophyta } \\
\text { : Angiospermae } \\
\text { : Monokotiledoneae } \\
\text { : Graminales } \\
\text { : Gramineae } \\
\text { : Bambusa } \\
: \text { Bambusa vulgaris }\end{array}$ \\
\hline
\end{tabular}




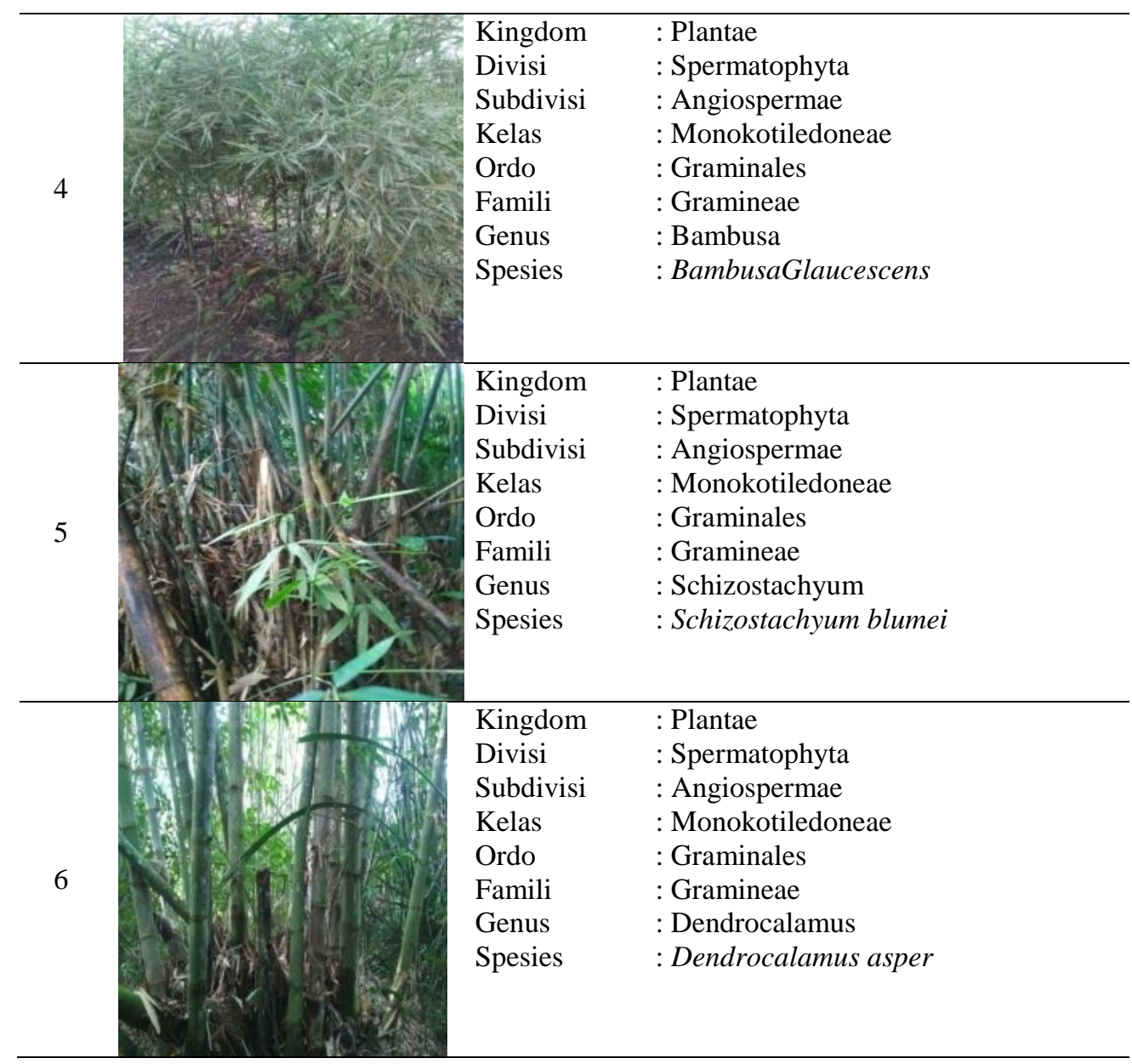

Setelah dilakukan identifikasi ada 6 spesies yang berbeda yaitu bambu apus/pring tali (Gigantochloa apus), bambu andong/pring lorek (Gigantochloa pseudoarundin), bambu ampel gading/pring kuning (Bambusa vulgaris), bambu hias/pring pagar (Bambusa glaucescens), bambu tamiang/pring suling (Schizostachyum blumei), dan bambu betung/pring petung (Dendrocalamus asper), dari 6 spesies ini terdapat 4 genus, yaitu (Gigantochloa, Bambusa, Dendrocalamus, dan Schizostachyum) menurut (Arinasa \& Peneng, 2013). Adapun bambu-bambu ini ditemukan dipingir sungai, dipingir jalan, diperkarangan rumah warga dan diperkebunan warga.

\section{PEMBAHASAN}

Keenam spesies bambu yang ada di Kecamatan Rawas Ulu Kabupaten Muratara akan di jabarkan dalam pembahasan sebagai berikut:

\section{Bambu Apus/Pring Tali (Gigantochloa apus)}

Bambu apus sering ditemukan dibelakang rumah warga, pingir jalan, dan tepi sungai yang tempatnya kering. Bambu memiliki panjang ruas pangkal batang $33 \mathrm{~cm}$, tegah batang $42 \mathrm{~cm}$, dan ujung batang $32 \mathrm{~cm}$. Pelepah bambu panjang 20 $\mathrm{cm}$ dan lebar $12 \mathrm{~cm}$. Tebal batang bambu pangkalnya $1 \mathrm{~cm}$, tengah $6 \mathrm{~mm}$, dan 
ujung $3 \mathrm{~mm}$. Diameter keliling pangkal batang $16 \mathrm{~cm}$, tengah $13 \mathrm{~cm}$, dan ujung 6 $\mathrm{cm}$. Panjang daun $24 \mathrm{~cm}$ dan lebar $4 \mathrm{~cm}$. Menurut Arinasa \& Peneng (2013) bambu apus rumpun rapat dan tegak, simpodial. Rebung hijau tertutup bulu coklat dan hitam. Pelepah bulu tidak mudah luruh tertutup bulu hitam atau coklat. Daun berwarnah hijau bagian bawah permukaan daun agak berbuluh, kuping pelepah daun kecil dan membulat. Menurut Kusnan (2007) bambu ini memiliki buku dengan diamter 9-15 meter, dengan dinding bulu antara 6-13 mm. Rumpun bambu apus mencapai cukup rapat dan batangnya bisa mencapai $20 \mathrm{~m}$. Bagian bawah bambu apus tidak memiliki ranting, bentuk batang teratu, ramping dan ukuran ratingnya tidak sama.

\section{Bambu Andong/Pring Lorek (Gigantochloa pseudoarundin)}

Bambu ini ditemukan pada tempat kering perkarangan belakang rumah warga, pingir jalan dan dekat sungai. Bambu memiliki panjang ruas pangkal batang $20 \mathrm{~cm}$, tengah $43 \mathrm{~cm}$, dan ujung batang $18 \mathrm{~cm}$. Panjang pelepah $13 \mathrm{~cm}$ dan lebar $7 \mathrm{~cm}$. Tebal pangkal batang $5 \mathrm{~mm}$, tengah $5 \mathrm{~mm}$, dan ujung $3 \mathrm{~mm}$. Diameter keliling pangkal batang $8 \mathrm{~cm}$, tengah $7 \mathrm{~cm}$ dan ujung $4 \mathrm{~cm}$. Panjang daun $35 \mathrm{~cm}$ dan lebar $4 \mathrm{~cm}$. Menurut Sutardi et al (2015) bambu andong memiliki batang berwarna hijau dengan garis-garis vertikal putih pada waktu masih segar dan berubah menjadi kuning krem atau kekuningan setelah mengering. Pada luasnya 5 $\mathrm{mm}$, hanya terdapat satu rumpun bambu dengan jumlah batang sekitar 68 buah, panjang bambu berkisar dari 17-22 $\mathrm{m}$, dengan diameter pada bagian pangkal sekitar 13,4 cm, tengah 10,9 $\mathrm{cm}$ dan ujung 5,3 cm, sedangkan ketebalan batang pada bagian pangkal 19,1 $\mathrm{mm}$, tengah 7,3 $\mathrm{mm}$ dan ujung 5,8 $\mathrm{mm}$. Bambu andong ini sangat berat, baik ketika masih basah maupun ketika sudah mengering.

\section{Bambu Ampel Gading/Pring Kuning (Bambusa vulgaris)}

Bambu ini ditemukan pada tempat kering perkarangan belakang rumah warga. Bambu memiliki panjang ruas pangkal bambu ampel gading $29 \mathrm{~cm}$, tengah $24 \mathrm{~cm}$, ujung $17 \mathrm{~cm}$ dan pelepah panjangnya $12 \mathrm{~cm}$ lebar $12 \mathrm{~cm}$. Sedangkan tebal batang bambu pangkal $9 \mathrm{~mm}$, tengah batang $7 \mathrm{~mm}$ dan ujung batang $4 \mathrm{~mm}$. Diameter keliling pangkal batang $13 \mathrm{~cm}$, tangah $10 \mathrm{~cm}$ dan ujung batang $4 \mathrm{~cm}$. Panjang daun $23 \mathrm{~cm}$ dan lebar $3 \mathrm{~cm}$. Menurut Yani (2012) bambu kuning memiliki rebung yang berwarna kuning, miang warna coklat halus dan banyak. Batang warna kuning strait hijau terang, dengan warna miang pada permukaan batang coklat dan tidak merata, tinggi 7-10 m, panjang ruas $33-48 \mathrm{~cm}$, diameter 5,5-7 $\mathrm{cm}$, tebal 2-4 $\mathrm{mm}$, pelepah yang membalut batang mudah luruh, warna miang pada pelepah coklat dan tidak merata daun pelepah tegak, bentuk kuping segi tiga dengan panjang kuping 2-3 mm, panjang bulu kejur 4-8 mm. Percabangan hampir sama besar dengan jumlah 12-21 cabang. Helai daun berwarna hijau dengan ukuran 10-29 $\mathrm{cm}$ dan lebar 3-5 cm. 


\section{Bambu Tamiang/Pring Suling (Schizostachyum blumei)}

Bambu ini ditemukan pada tempat kering pingir jalan dan dekat sungai. Bambu memiliki panjang ruas pangkal batang $95 \mathrm{~cm}$, tengah $71 \mathrm{~cm}$ dan ujung 61 $\mathrm{cm}$. Panjang pelepah $18 \mathrm{~cm}$, lebar $9 \mathrm{~cm}$, tebal batang pangkal $1,3 \mathrm{~cm}$, tegah $9 \mathrm{~mm}$, dan ujung $5 \mathrm{~mm}$. Diameter keliling pangkal batang $10 \mathrm{~cm}$, tengah $7 \mathrm{~cm}$ dan ujung batang $3 \mathrm{~cm}$. Panjang daun $27 \mathrm{~cm}$ dan lebar $5 \mathrm{~cm}$. Menurut Arinasa \& Peneng (2013) rumpun bambu suling simpodial, rapat dan tegak. Rebung hijau tertutup bambu putih hingga coklat. Bulu tingginya mencapai 7-12 m, sedangkan diameter bambunya 1-3 cm, ruas panjangnya $65-75 \mathrm{~cm}$, dindingnya tipis $3 \mathrm{~mm}$, buku-buku tampak dengan jelas. Percabangan sekitar 1,5 $\mathrm{m}$ di atas tanah bahkan lebih dengan cabang yang sama besar.

\section{Bambu Hias (Bambusa glaucescens)}

Bambu ini ditemukan pada tempat kering perkarangan rumah warga. Bambu memiliki panjang ruas pangkal batang adalah $8 \mathrm{~cm}$, tengah batang $13 \mathrm{~cm}$ dan ujung batang $7 \mathrm{~cm}$. Panjang pelepah $9 \mathrm{~cm}$ dan lebar pelepah $4 \mathrm{~cm}$. Tebal pangkal batang $8 \mathrm{~mm}$, tengah batang $6 \mathrm{~mm}$ dan ujung batabg $3 \mathrm{~mm}$. Diameter keliling pangkal batang 2,5 cm, tengah batang $2 \mathrm{~cm}$ dan ujung batang $1,5 \mathrm{~cm}$. Panjang daun $11 \mathrm{~cm}$ dan lebar daun 1,5 cm. Menurut Yani (2012) bambu hias rebungnya hijau pucat tertutup miang hitam halus dan sedikit. Batang warna hijau, pada permukaan batang terdapat lapisan lilin, dan bermiang pada permukaan batang halus, licin, tegak melengkung pada ujungnya, tinggi 4-6 m, panjang ruas 20-30 cm, diameter $1-1,5 \mathrm{~cm}$, tebal $2-5 \mathrm{~mm}$, pelepah yang membalut batang mudah luruh berwarna hijau pucat, warna miang pada pelepah hitam halus dan sedikit, daun pelepah tegak, kuping tidak nampak. Percabangan sama besar dengan jumlah 9-13 cabang. Helai daun berwarna hijau dengan ukuran 15-28 x 4$5 \mathrm{~cm}$.

\section{Bambu Betung/Pring Petung (Dendrocalamus asper)}

Bambu ini ditemukan pada tempat kering perkarangan belakang rumah warga, pingir jalan dan dekat sungai. Bambu memiliki Panjang ruas pangkal batang $31 \mathrm{~cm}$, tengah $39 \mathrm{~cm}$, dan ujung batang $33 \mathrm{~cm}$. Panjang pelepah $42 \mathrm{~cm}$ dan lebar $47 \mathrm{~cm}$. Tebal batang pangkal bambu $2,5 \mathrm{~cm}$, tengah $1,8 \mathrm{~cm}$, dan ujung batang $7 \mathrm{~mm}$. Diameter keliling pangkal batang $31 \mathrm{~cm}$, tengah batang $28 \mathrm{~cm}$, dan ujung batang $12 \mathrm{~cm}$. Panjang daun $28 \mathrm{~cm}$ dan lebar $5 \mathrm{~cm}$. Menurut Arinasa \& Peneng (2013) rumpun bambu betung rapat dan tegak, simpodial. Rebungnya hitam keunguan, tertutup oleh bulu seperti beludru, berwarna coklat hingga kehitaman. Bulu tingginya mencapai $20-30 \mathrm{~cm}$, tegak dengan ujung melengkung. Percabangan terdapat dibagian tengah bulu atau 1,5-3 $\mathrm{m}$ dari permukaan tanah, yang terdiri atas 5-11 cabang, 1 cabang lateral lebih besar dari cabang lainnya. 


\section{Ekologi Jenis Bambu (Bambusa sp) di Kecamatan Rawas Ulu Kabupaten Muratara}

Jumlah rumpun bambu yang di temui sebanyak 95 rumpun yang masingmasing tersebar dari desa Simpang Nibung, Sungai Jauh, Sungai Kijang, Pasar Surulangun, Sukomoro, Sungai Baung, Lesung Batu Muda, Lesung Batu Tua, Lubuk Kemang sampai Remban.

\section{Simpang Nibung}

Desa simpang nibung ini terdapat 9 rumpun bambu dan 5 spesies bambu yaitu bambu apus yang terdiri dari 3 rumpun yang habitatnya ditempat kering terdapat dipingir jalan dan dibelakang rumah warga dimana memiliki $\mathrm{pH}$ tanah 5,8, 6,0, 5,1 dan suhu $30,32{ }^{\circ} \mathrm{C}$ dengan kelembaban tanah 72, 71, 62. Sedangkan bambu andong yang terdiri dari 2 rumpun yang habitatnya ditemapat kering terdapat dipingir jalan dan didekat rumah sekolahdimana memiliki $\mathrm{pH}$ tanah yaitu 6,1, 6,2 dan suhu $27{ }^{\circ} \mathrm{C}$ dengan kelembaban tanah 53, 60. Sedangkan bambu gading yang terdiri dari 1 rumpun yang memilki $\mathrm{pH}$ tanah yaitu 5,9 dan suhu 30 ${ }^{0} \mathrm{C}$ dengan kelembaban tanah 67. Sedangkan bambu tamiang yang terdiri 1 rumpun yang habitatnya ditempat kering yang terdapat dibelakang rumah warga dimana memiliki $\mathrm{pH}$ tanah 5,9 dan suhu $28{ }^{\circ} \mathrm{C}$ dengan kelembaban tanah 55 . Sedangkan bambu betung yang terdiri dari 2 rumpun yang habitatnya ditempat yang tidak terlalu kering dipingir sungai dan dibelkang rumah warga dimana memiliki pH tanah 5,7, 6,1 dan suhu 27, $30{ }^{\circ} \mathrm{C}$ dengan kelembaban tanah 54, 57.

\section{Sungai Jauh}

Desa sungai jauh ini terdapat 10 rumpun bambu dan 4 spesies bambu yaitu bambu apus yang terdiri dari 4 rumpun yang habitatnya ditempat kering yang terdapat dipingir jalandan dibelakang rumah warga dimana memilki $\mathrm{pH}$ tanah dari 5,3, 6,2, 6,1, 6,1 dan suhu 29, 30 ${ }^{\circ} \mathrm{C}$ dengan kelembaban tanah 63, 71, 63, 71 Sedangkan bambu andong yang terdiri dari 4 rumpun bambu yang habitatnya ditempat kering yang terdapat di belkang rumah warga, didekat rumah warga dandipingir jalan dimana memilki $\mathrm{pH}$ tanah 5,2, 6,5, 6,3, 6,3 dan suhu 29, $30{ }^{\circ} \mathrm{C}$ dengan kelembaban tanah $61,71,63,61$. Sedangkan bambu pagar yang terdiri dari 1 rumpun yang habitatnya ditempat kering didepan rumah warga dimana memiliki pH tanah 49 dan suhu $29{ }^{\circ} \mathrm{C}$ dengan kelembaban tanah 51. Sedangkan bambu betung yang terdiri dari 1 rumpun yang habitatnya ditempat yang tidak terlalu kering dimana memilki $\mathrm{pH}$ tanah 6,1 dan suhu $29{ }^{0} \mathrm{C}$ dengan kelembaban tanah 57.

\section{Sungai Kijang}

Desa sungai kijang ini terdapat 8 rumpun bambu dan 2 spesies bambu yaitu bambu apus yang terdiri dari 6 rumpun yang habitatnya ditempat kering yang terdapat dipingir jalan dan dibelkang rumah warga dimana memilki $\mathrm{pH}$ 
tanah dari 5,1, 6,3, 5,1, 5,2, 5,5, 5,5 dan suhu $29,30{ }^{0} \mathrm{C}$ dengan kelembaban tanah 50, 50, 61, 61, 63. Sedangkan bambu andong yang terdiri dari 2 rumpun bambu yang habitatnya ditempat yang tidak terlalu kering dimana memilki $\mathrm{pH}$ tanah 6,1 , 6,5 dan suhu $25,26{ }^{\circ} \mathrm{C}$ dengan kelembaban tanah 70, 71.

\section{Pasar Surulangun}

Desa pasar surulangun ini terdapat 12 rumpun bambu dan 5 spesies bambu yaitu bambu apus yangdari 6 rumpun yang habitatnya ditempat keringan yang terdapat dipinggir jalan, dibelakang rumah wargadan tempat yang tidak terlalu yang kering di pingir sungaiterdiri dimana memilki $\mathrm{pH}$ tanah dari 5,2, 5,5, 6,1, 5,0, 6,1 dan suhu 29,30 ${ }^{\circ} \mathrm{C}$ dengan kelembaban tanah 63, 71, 63, 69, 6471 . Sedangkan bambu andong yang terdiri dari 2 rumpun bambu yang habitatnya ditempat kering yang terdapat dibelakang rumah warga dimana memilki $\mathrm{pH}$ tanah 6,9, 7,0 dan suhu $30{ }^{0} \mathrm{C}$ dengan kelembaban tanah 69, 71. Sedangkan bambu gading yang terdiri dari 1 rumpun yang habitatanya ditempat yang terdapat di belakang rumah warga dengan $\mathrm{pH}$ tanah 5,2 dan suhu $30^{\circ} \mathrm{C}$ dengan kelembaban tanah 52. Sedangkan bambu pagar yang terdiri dari 1 rumpun yang habitatanya ditempat kering di depan rumah warga dimana memilki $\mathrm{pH}$ tanah 6,3 dan suhu 29 ${ }^{0} \mathrm{C}$ dengan kelembaban tanah 67. Sedangkan bambu betung yang terdiri dari 2 rumpun yanghabitatnya ditempat yang tidak terllu kering dipingir sungai dimana memilki pH tanah 5,3, 6,3 dan suhu $29{ }^{\circ} \mathrm{C}$ dengan kelembaban tanah 59, 62.

\section{Sukomoro}

Desa sukomoro ini terdapat 6 rumpun bambu dan 2 spesies bambu yaitu bambu apus yang terdiri dari 4 rumpun yang habitatnya ditempat kering dipingir jalan, dibelakang rumah warga dan ditempat yang tidak terlalu kering dingir sungai dimana memilki $\mathrm{pH}$ tanah dari 5,3, 5,0, 6,1, 6,6 dan suhu $28^{0} \mathrm{C}$ dengan kelembaban tanah 53, 69, 61, 63 . Sedangkan bambu andong yang terdiri dari 2 rumpun bambu yang habitatnya ditempat kering yang terdapat dipingir jalan dan tempat yang tidak terlalukering dingir sungai dimana memilki $\mathrm{pH}$ tanah 6,1, 6,2 dan suhu $28^{\circ} \mathrm{C}$ dengan kelembaban tanah 54, 57.

\section{Sungai Baung}

Desa sungai baung ini terdapat 10 rumpun bambu dan 4 spesies bambu yaitu bambu apus yang terdiri dari 4 rumpun yang habitatnya ditempat kering yang terdapat dipingir jalan, dibelakang rumah warga dan tempat yang tidak terlalu kering dipingir sungai dimana memilki $\mathrm{pH}$ tanah dari 6,3, 5,3, 6,2, 6,6 dan suhu $29{ }^{\circ} \mathrm{C}$ dengan kelembaban tanah 53, 63, 66, 62. Sedangkan bambu andong yang terdiri dari 3 rumpun bambu yang habitatanya ditempat kering yang terdapat dipingir jalan, didekat rumah warga dan yang tidak terlalu kering dipingir sungai dimana memilki pH tanah 5,1, 5,8, 7,0 dan suhu $29{ }^{0} \mathrm{C}$ dengan kelembaban tanah $62,70,71$. Sedangkan bambu ampel kuning yang terdiri dari 1 rumpun yang 
habitatnya ditempat kering dibelakang rumah waraga dimana dengan $\mathrm{pH}$ tanah 6,3 dan suhu $29{ }^{0} \mathrm{C}$ dengan kelembaban tanah 67. Sedangkan bambu betung yang terdiri dari 2 rumpun yang habitatnya ditempat yang tidak terlalu kering dipingir sungai dimana memilki $\mathrm{pH}$ tanah $6,1,6,2$ dan suhu $28{ }^{\circ} \mathrm{C}$ dengan kelembaban tanah 53, 60 .

\section{Lesung Batu Muda}

Desa lesung batu muda ini terdapat 13 rumpun bambu dan 6 spesies bambu yaitu bambu apus yang terdiri dari 6 rumpun yang habitatnya ditempat kering yang terdapat dipingir jalan dan dibelakang rumah warga dimana memiliki $\mathrm{pH}$ tanah 5,3, 6,6, 6,3, 5,1 6,3, 6,6 dan suhu 30, $32{ }^{\circ} \mathrm{C}$ dengan kelembaban tanah $62,61,63,63,53,72$. Sedangkan bambu andong yang terdiri dari 1 rumpun yang habitatnya ditempat kering yang terdapat dipingir jalan dimana memiliki $\mathrm{pH}$ tanah yaitu 5,4 dan suhu $25^{\circ} \mathrm{C}$ dengan kelembaban tanah 71 . Sedangkan bambu gading yang terdiri dari 1 rumpun yang habitatnya ditempat kering yang terdapat dibelakang rumah warga dimana memilki $\mathrm{pH}$ tanah yaitu 5,4 dan suhu $26^{\circ} \mathrm{C}$ dengan kelembaban tanah 70. Sedangkan bambu pagar yang terdiri 1 rumpun yang habitatnya ditempat kering yang terdapat didepan rumah warga dimana memiliki pH tanah 5,6 dan suhu $28{ }^{0} \mathrm{C}$ dengan kelembaban tanah 71. Sedangkan bambu tamiang yang terdiri 2 rumpun yang habitatnya ditempat yang tidak terlalu kering yang terdapat dingir sungai dimana memiliki $\mathrm{pH}$ tanah 5,3, 6,2 dan suhu 28 ${ }^{0} \mathrm{C}$ dengan kelembaban tanah 69, 72. Sedangkan bambu betung yang terdiri dari 3 rumpun yang habitatnya di tempat yang tidak terlalu lering dipingir sungai dan dikebun warga dimana memiliki $\mathrm{pH}$ tanah $5,1,5,3,7,0$ dan suhu $28^{0} \mathrm{C}$ dengan kelembaban tanah 55, 63, 71 .

\section{Lesung Batu Tua}

Desa lesung batu tua ini terdapat 10 rumpun bambu dan 4 spesies bambu yaitu bambu apus yang terdiri dari 5 rumpun yang habitatnya ditempat yang kering dipingir jalan dan dibelkang rumah warga dimana memiliki $\mathrm{pH}$ tanah 5,1, 5,5, 6,2, 6,2, 6,6 dan suhu 28, $29{ }^{\circ} \mathrm{C}$ dengan kelembaban tanah 52, 53, 69, 69, 70. Sedangkan bambu andong yang terdiri dari 2 rumpun yang habitatnya ditempat yang tidak terlalu kering dipingir sungai dimana memiliki $\mathrm{pH}$ tanah yaitu 5,8, 6,9 dan suhu $28{ }^{\circ} \mathrm{C}$ dengan kelembaban tanah 62,70 . Sedangkan bambu tamiang yang terdiri 1 rumpun yang habitatnya ditempat yang tidak terlalu kering yang terdapat dipingir sungai dimana memiliki $\mathrm{pH}$ tanah 6,1 dan suhu $27{ }^{\circ} \mathrm{C}$ dengan kelembaban tanah 72. Sedangkan bambu betung yang terdiri dari 2 rumpun yang habitatnya ditempat yang kering dikebun warga dimana memiliki $\mathrm{pH}$ tanah 5,2-7,1 dan suhu $27{ }^{0} \mathrm{C}$ dengan kelembaban tanah 55-71. 


\section{Lubuk Kemang}

Desa lubuk kemang ini terdapat 11 rumpun bambu dan 5 spesies bambu yaitu bambu apus yang terdiri dari 4 rumpun yang habitatnya ditempat kering yang terdapat dipingir jalan dan dibelakang rumah warga dimana memiliki $\mathrm{pH}$ tanah 5,0, 5,3, 6,2, 6,6 dan suhu $29{ }^{\circ} \mathrm{C}$ dengan kelembaban tanah 63,69, 69, 71. Sedangkan bambu andong yang terdiri dari 2 rumpun yang habitatnya ditempat kering yang tedapat dipingir jalan dimana memiliki $\mathrm{pH}$ tanah yaitu 5,2, 6,1 dan suhu $29{ }^{0} \mathrm{C}$ dengan kelembaban tanah 69 , 70. Sedangkan bambu gading yang terdiri dari 1 rumpun yang habitatnya ditempat kering dibelakang rumah warga diaman memilki pH tanah yaitu 6,8 dan suhu $29^{\circ} \mathrm{C}$ dengan kelembaban tanah 61 . Sedangkan bambu tamiang yang terdiri 2 rumpun yang habitatnya ditempaat yang tidak terlalu kering yang terdapat dipingir sungai diaman memiliki $\mathrm{pH}$ tanah 5,2, 6,1 dan suhu $28{ }^{\circ} \mathrm{C}$ dengan kelembaban tanah 57, 59. Sedangkan bambu betung yang terdiri dari 2 rumpun yang habitatnya ditempat yang tidak terlalu kering dipingir sungai dimana memiliki $\mathrm{pH}$ tanah 5,7, 6,3 dan suhu $28{ }^{0} \mathrm{C}$ dengan kelembaban tanah 59, 61 .

\section{Remban}

Desa remban ini terdapat 5 rumpun bambu dan 3 spesies bambu yaitu bambu apus yang terdiri dari 3 rumpun yang habitatnya ditempat kering dipingir jalan dan dibelkang rumah warga diaman memiliki $\mathrm{pH}$ tanah 5,2, 6,2, 6,2 dan suhu $30{ }^{\circ} \mathrm{C}$ dengan kelembaban tanah $56,63,71$. Sedangkan bambu andong yang terdiri dari 1 rumpun yang habitatnya ditempat kering yang terdapat dipingir jalan dimana memiliki pH tanah yaitu 5,9 dan suhu $30{ }^{\circ} \mathrm{C}$ dengan kelembaban tanah 67. Sedangkan bambu tamiang yang terdiri 1 rumpun yang habitatnya ditempat yang tidak terlalu kering yang tedapat pingir sungai dimana memiliki $\mathrm{pH}$ tanah 5,9 dan suhu $29{ }^{\circ} \mathrm{C}$ dengan kelembaban tanah 78. Dari uraian-uraian ekologi di atas dapat disimpulkan bawah bambu dapat hidup ditempat kering maupun basah dengan $\mathrm{pH}$ tanah, kelembaban tanah dan suhu udara yang berbeda-beda. Menurut Kusnan (2007) Rumpun-rumpun bambu dengan berbagai jenisnya tumbuh secara liar yaitu ditepi-tepi sungai, pergunungan, perkampungan dan perdesaan. Menurut Prasetiyo (2009) bambu sangat menghendaki tempat tumbuh dengan keadaan $\mathrm{pH}$ tanah antara 5,0 sampai 6,5 dan pada tanah yang subur bambu dapat tumbuh dengan baik, sedangkan suhu dan kelembaban yang dikehendaki bambu adalah $8,8{ }^{\circ} \mathrm{C}$ sampai $36{ }^{\circ} \mathrm{C}$ dan kelembaban minimum $80 \%$. Sedangkan menurut Yani (2012) pertumbuhan bambu tidak terlepas dari pengaru kondisi lingkungan tempat tumbuh. Adapun faktor-faktor lingkungan yang berkaitan dengan syarat tumbuh bambu adalah tanah dengan $\mathrm{pH}$ 5,6-6,2 dan suhu 8,8-36 ${ }^{\circ} \mathrm{C}$ dan kelembaban tanah 80\%. Sedangkan menurut Pusat Penyuluhan Kehutanan (1996) faktor iklim yang mempengaruhi pertumbuhan hidup bambu adalah suhu 8- $38{ }^{\circ} \mathrm{C}$ dan kelembaban 80\%.Dengan demikian, kondisi lingkungan dari 10 Desa diatas memenuhi syarat untuk tumbuhnya bambu. 


\section{Bambu Apus/Pring Tali}

Berdasarkan hasil wawancara bambu apus banyak digunakan sebagai anyaman, tempat duduk didepan rumah, tampah dan tali temali. Sedangkan menurut Arinasa \& Peneng (2013) bambu apus banyak digunakan dalam industri kerajinan rumah tangga, seperti di bidang konstruksi, mebel, payung, peralatan dapur, tali temali serta sarana upacara hindu. Di bidang konstruksi bambu ini digunakan sebagai bangunan rumah dan atap. Banyak perajin mebel yang membuat meja, kursi, lemari, dipan, atau tempat tidur, rak dan lain sebagainya.

\section{Bambu Andong/Pring Lorek}

Berdasarkan wawancara bambu andong dapat dimanfaatkan sebagai tiang jemuran pakaian, tempat duduk didepan rumah dan congkok batang buah pohon. Sedangkan menurut Sutardi et al (2015) bambu ini dapat dimanfaatkan untuk konstruksi berat seperti membuat jembatan dan memiliki kualitas serat sebagai bahan baku pulp maupun kertas.

\section{Bambu Ampel Gading/Pring Kuning}

Berdasarkan wawancara bambu ampel banyak dimanfaatkan sebagai bahan konstruksi ringan seperti digunakan untuk membuat kandang ternak, pagar rumah dan juga sering digunakan untuk membuat ranajang tidur. Sedangkan menurut Arinasa \& Peneng (2013). bambu ampel gading digunakan sebagai bahan konstruksi bangunan, seperti rumah sederhana, steger, gabuk, dapur, gudang, pagar, kandang ternak dan sebaginya. Selain itu, rebung dari varietas yang berwarna kuning menurut informasi dari penduduk dapat digunakan untuk mengobati penyakit liver.

\section{Bambu Tamiang/Pring Suling}

Berdasarkan wawancara bambu suling ini dapat dimanfaatkan untuk membuat kerajinan suling, pagar dan pancing. Sedangkan menurut Arinasa \& Peneng (2013) bambu suling dapat dimanfaatkan untuk membuat kerajinan rumah tangga salah satunya membuat gedeg, krei dan sokasi (bakul).

\section{Bambu Hias/Pring Pagar}

Berdasarkan wawancara bambu hias dapat dimanfaatkan sebagai pagar dan tanaman hias. Sedangkan menurut Muhtar et al (2017) bambu hias dapat dimanfaatkan sebagai tanaman hias, yang terdapat di perkarangan rumah masyarakat.

\section{Bambu Betung/Pring Petung}

Berdasarkan wawancara bambu betung dimanfaatkan sebagai kandang ternak, pagar, tiang dan pipah air. Sedangkan menurut Arinasa \& Peneng (2013) 
bambu betung dapat digunakan dalam industri kerajinan rumah tangga seperti tiang rumah, kerangka rumah, atap, lantai hingga dinding.

Dari uraian diatas bawah bambu memiliki banyak manfaat dimana bambu dapat dimanfaatkan sebagai bahan untuk konstruksi ringan dan alat-alat rumah tangga. Menurut Kusnan (2007) bambu memiliki niali ekonomis. Dimana bambu dapat diolah menjadi bebagai produk, mulai dari peralatan rumah tangga hinga cendra mata. Sedangkan menurut Muhtar et al (2017) bambu merupakan tanaman dengan manfaat besar untuk memenuhi kebutuhan hidup sehari-hari. Pemanfaatan bambu diantaranya sebagai bahan konstruksi rumah, kursi dan pagar.

\section{SIMPULAN}

Berdasarkan hasil penelitian dan pembahasan dapat disimpulkan bahwa di Kecamatan Rawas Ulu Kabupaten Muratara adalah terdapat 4 genus dan 6 jenis bambu yang hidup berbeda. Keempat jenis genus tersebut adalah Gigantochloa, Bambusa, Densrocalamus, dan Schizoctachyum sedangkan keenam jenis bambu tersebut adalah Gigantochloa apus bambu apus/pring tali, memiliki $\mathrm{pH}$ tanah 5,16,6 dan suhu udara $26-30^{\circ} \mathrm{C}$ dengan kelembaban tanah $52-71 \%$ (kadar air); Gigantochloa pseudoarundin bambu andong/pring lorek, memiliki $\mathrm{pH}$ tanah 5,87,0 dan suhu udara $25-30^{\circ} \mathrm{C}$ dengan kelembaban tanah $54-71 \%$ (kadar air); Bambusa vulgaris bambu ampel gading/pring kuning, bambu ampel gading memiliki pH tanah 5,2-6,3 dan suhu udara $29-30^{\circ} \mathrm{C}$ dengan kelembaban tanah 61$71 \%$ (kadar air); Bambusa glaucescensbambu hias memiliki pH tanah 4,9-6,3 dan suhu udara $28-30^{\circ} \mathrm{C}$ dengan kelembaban tanah $51-71 \%$ (kadar air); Bambusa glaucescens bambu pagar/pring pagar, memilki $\mathrm{pH}$ tanah 6,3 dan suhu $29{ }^{0} \mathrm{C}$ dengan kelembaban tanah 67\% (kadar air); Schizoctachyum blumei bambu tamiang/pring suling, Densrocalamus asper bambu betung/pring petung. ); Dendrocalamus asperbambu betung memiliki $\mathrm{pH}$ tanah 5,2-7,0 dan suhu udara 27-30 ${ }^{\circ} \mathrm{C}$ dengan kelembaban tanah 53-71\% (kadar air).

\section{DAFTAR PUSTAKA}

Abrori, R. (2016). Ekplorasi dan Karakteristik Bambu (Poaceae-Bambusoideae) di Kecamatan Tirtoyudo Kabupaten malang. Skripsi. Fakultas Sains dan Teknologi Universitas Islam Negeri Maulana Malik Ibrahim Malang.

Arinasa, I.B.K. \& Peneng, I.N. (2013). Jenis-jenis Bambu di Bali dan Potensinya. Jakarta: LIPI Press.

Kusnan, M.R. (2007). Kreasi dari Kayu dan Bambu. Yogyakarta: Saka Mitra Kompetensi Anggota IKAPI.

Muhtar, D.F., Sinyo, Y. \& Ahmad, H. (2017). Pemanfaatan Tumbuhan Bambu Oleh Masyarakat Di Kecamatan Oba Utara Kota Tidore Kepulauan.Jurnal Santifika MIPA, 1(1).

Rastiyo, S. (2009). Identifikasi Potensi dan Pemasaran Produk Dari Hutan Rakyat Bambu (Studi Kasus: Desa Pertumbuhan Kec. Wampu Kab. Langkat. Skripsi Fakultas Pertanian Universitas Sumatra Utara. 
Pusat Penyuluhan Kehutanan. (1996). Pengembangan Budidaya Bambu. Yogyakarta: Dapertemen Kehutanan.

Sinyo, Y., Sirajudin, N., \& Hasan, S. (2017).Pemanfaatan Tumbuhan Bambu: Kajian Empiris Etnoekologi Pada Masyarakat Kota Tiidore Kepulauan. Jurnal Sanitifika, 1(2); 34-44

Sugiyono. (2015). Metode Penelitian Pendidikan: Pendekatan Kuantitatif, Kualitatif, $R \& D$. Bandung: Alfabeta.

Sutardi, S. R., Nadjid, N., Muslich, M., Jasni., Sulastiningsih, I.M. \& Komariyati, S.(2015). Seri Paket Iptek Informasi Sifat Dasar dan Kemungkinan Penggunaan 10 Jenis Bambu. Bogor: IPB Press.

Tim Elsppat. (1997). Pengawetan Kayu dan Bambu. Jakarta: Puspa Swara.

Yani, A.P. (2012). Keanekaragaman dan Populasi Bambu di Desa Talang Pauh Bengkulu Tengah. Jurnal Exacta, 10(1); 60-70. 